\title{
Nutrients and Cholesterol of Eggs Affected by Dried Tomato Meal in Laying Hens Diet
}

\author{
Jein R. Leke", Jet S. Mandey", Fredy J. Nangoy" \\ \# Animal Production Department, Animal Husbandry Faculty, Sam Ratulangi University, Manado 95115, Indonesia \\ E-mail:rinileke@yahoo.com,frd_dx@yahoo.com \\ *Animal Nutrition Department, Animal Husbandry Faculty, Sam Ratulangi University, Manado 95115, Indonesia \\ E-mail: jetsm_fapet@yahoo.co.id
}

\begin{abstract}
One hundred MB 402 laying hens (36 weeks of age) were used for the study. The birds were divided into five experimental diets and each was divided into four replicate groups of five birds per replicate. The control diet (based diet) was formulated to contain $51 \%$ corn, $14 \%$ rice bran, $7 \%$ fish meal, $6 \% \mathrm{CaCO3}$, and $22 \%$ commercial diet. Tomato meal was included in four experimental diets at levels of $2,4,6,8 \%$ to substitute based diet. The treatments were: $R 0=100 \%$ based diet $(\mathrm{BD})+0 \%$ tomato meal $(\mathrm{TM}) ; \mathrm{R} 1=98 \% \mathrm{BD}+2 \% \mathrm{TM} ; \mathrm{R2}=96 \% \mathrm{BD}+4 \% \mathrm{TM} ; \mathrm{R3}=94 \% \mathrm{BD}+6 \% \mathrm{TM}$; and R4 = 92\% BD + 8\% TM. Chemical composition of tomato meal were: $16.73 \%$ crude protein, $1.53 \%$ fat, $30.94 \%$ crude fiber, $0.98 \% \mathrm{Ca}, 1.20 \% \mathrm{P}$, and $2416 \mathrm{Kcal} / \mathrm{kg} \mathrm{ME}$. Feed and water were provided for ad libitum. The study was conducted over a period of 8 weeks, and data were collected on nutrients of eggs: crude protein, fat, carbohydrate, and cholesterol of eggs. Proximate analysis eggs was determined by the methods of AOAC (1990), and cholesterol was determined by Libermann and Burchad method. Data were analyzed by one-way analysis of variance (ANOVA). The treatment means were compared using Duncan's multiple range test. The results showedthat no differences in hen egg nutrients and cholesterol between treatments R1, R2, R3, and R4 compared to treatment R0 (control). It can be concluded that tomato meal can be used as an alternative feedstuff in laying hen diets to substitute based diet, at inclusion levels up to $8 \%$ without negative effects on egg quality.
\end{abstract}

Keywords - Egg, tomato meal, nutrient, cholesterol

\section{INTRODUCTION}

Egg consumption has decreased in some parts of the world in the last decades. However, the value of eggs as human food has not. Moreover, there has been an increasing effort to improve its nutritional value lately [1]. Nowadays the public concern is oriented toward food safety, so it is important to look for new alternative natural ingredients that could be used in animal production as food.Reference [2] stated that tomato extract important for its role of betacarotene precursor for its immunostimulant effects and for its dietary and nutritional value in human health. Tomato are excellent sources of potassium, folate, and vitamins A, C, and $\mathrm{E}$, but are superior sources of $\alpha$-tocopherol and vitamin C. Fiber is another dietary component and appreciable amounts are found in tomato. Tomatoes also contains a variety of phytochemicals, including carotenoids and polyphenols [3].

The nutritional value of tomato can provide the poultry industry with an alternative feedstuff. Researchers reported that tomato meal that was included at levels of 80 or 150 $\mathrm{g} / \mathrm{kg}$ in diets fed to laying hens without negative effect on egg production and egg quality [4]. Tomato powder supplementation increased egg production persistency and increased carotenoids and vitamin A contents in egg yolk [5]. Then, reference [6] reported that tomato extract diet resulted in a significant lycopene carry over and the intensity of egg yolk colour was influenced by dietary lycopene supplementation. Dried tomato pulp fed to lying hens at an inclusion level of $120 \mathrm{~g} / \mathrm{kg}$ diet resulted in similar egg production and feed consumption compared to hens fed a corn-soybean meal control diet [7]. While, dried tomato pulp can be used as an alternative feedstuff in laying hen diets at inclusion levels up to $100 \mathrm{~kg} / \mathrm{t}$ without negative effects on performance and egg quality [8]. There are no reported studies on the nutritional value of eggs of laying hens fed tomato meal. Thus, the objective of this research was to evaluate the use of tomato meal in diet of laying hens to nutrients of egg and cholesterol of egg. 


\section{MATERIALS AND METHODS}

\section{A. Preparation of tomato meal}

The tomatoes were washed, cut, and sun-dried to constant weight for 3-5 days. Part of tomato then was ground to fine powder using mortar and pestle. After that, mixed with other ingredients to compound the feed.

\section{B. Birds, feeding and management}

One hundred MB 402 laying hens (36 weeks of age) were used for the study. The birds were divided into five experimental diets and each was divided into four replicate groups of five birds per replicateusing completely randomized design. The control diet (based diet)was formulated to contain $51 \%$ corn, $14 \%$ rice bran, $7 \%$ fish meal, $6 \% \mathrm{CaCO} 3$, and $22 \%$ commercial diet. Tomato meal was included in four experimental diets at levels of 2, 4, 6, $8 \%$ to substitute based diet. The treatments were: $\mathrm{R} 0=100 \%$ based diet $(\mathrm{BD})+0 \%$ tomato meal $(\mathrm{TM}) ; \mathrm{R} 1=98 \% \mathrm{BD}+$ $2 \% \mathrm{TM} ; \mathrm{R} 2=96 \% \mathrm{BD}+4 \% \mathrm{TM} ; \mathrm{R} 3=94 \% \mathrm{BD}+6 \% \mathrm{TM}$; and $\mathrm{R} 4=92 \% \mathrm{BD}+8 \%$ TM.Chemical composition of tomato meal were: $20.73 \%$ crude protein, $1.53 \%$ fat, $30.94 \%$ crude fiber, $0.98 \% \mathrm{Ca}, 1.20 \% \mathrm{P}$, and $2416 \mathrm{Kcal} / \mathrm{kg} \mathrm{ME}$, and chemical composition of the diets are shown in Table 1.

Feed and water were provided for ad libitum using a feeding through and a water through. Diets were presented in mash form. Eggs were collected two times a day. The study was conducted over a period of 8 weeks. Data were collected on nutrients of eggs: crude protein, fat, carbohydrate, and cholesterol of eggs.

\section{Chemical analysis}

Proximate analysis of eggs was determined by the methods of AOAC [9].Crude protein was determined by multiplying crude nitrogen by 6.25 while total carbohydrate was obtained by simple difference. Cholesterol was determined by Libermann and Burchad method [10]

\section{Statistical analysis}

Data were analyzed by one-way analysis of variance (ANOVA). Probability values $<0.05$ were taken to indicate statistical significance. The treatment means were compared using Duncan's multiple range test [11].

TABLE I

Chemical Composition of The Diets

\begin{tabular}{|l|c|c|c|c|c|}
\hline \multirow{2}{*}{ Nutrients } & \multicolumn{5}{|c|}{ Diets } \\
\cline { 2 - 6 } & $\mathbf{R 0}$ & $\mathbf{R 1}$ & $\mathbf{R 2}$ & $\mathbf{R 3}$ & $\mathbf{R 4}$ \\
\hline Crude protein (\%) & 17.49 & 17.47 & 17.45 & 17.44 & 17.42 \\
\hline Fat (\%) & 6.63 & 6.61 & 6.59 & 6.57 & 6.56 \\
\hline Crude fiber (\%) & 4.31 & 5.41 & 6.50 & 7.24 & 8.69 \\
\hline Ca (\%) & 2.76 & 2.75 & 2.69 & 2.66 & 2.56 \\
\hline P (\%) & 1.42 & 1.16 & 1.42 & 1.41 & 1.40 \\
\hline ME (Kcal/kg) & 2766 & 2759 & 2752 & 2745 & 2738 \\
\hline
\end{tabular}

TABLE II

EFFECT OF TOMATO MEAL ON NUTRIENTS AND CHOLESTEROL OF WHOLE EGGS

\begin{tabular}{|c|c|c|c|c|c|}
\hline \multirow{2}{*}{ Diet } & \multicolumn{4}{|c|}{ Parameters } \\
\cline { 2 - 6 } & Water & Crude Protein & Fat & Carbohydrate & Cholesterol \\
\cline { 2 - 6 } & \multicolumn{4}{|c|}{ \% on Dry Matter Basis $/ 100 \mathrm{~g}$} \\
\hline R0 (0\% TM) & $74.99 \pm 0.56$ & $10.28 \pm 0.82$ & $8.14 \pm 0.28$ & $1.36 \pm 0.18$ & $181.91 \pm 4.70$ \\
\hline R1 (2\% TM) & $75.60 \pm 0.56$ & $10.64 \pm 0.48$ & $8.25 \pm 0.26$ & $1.49 \pm 0.24$ & $183.80 \pm 8.89$ \\
\hline R2 (4\% TM) & $74.84 \pm 0.43$ & $10.49 \pm 0.77$ & $8.41 \pm 0.27$ & $1.19 \pm 0.56$ & $189.19 \pm 7.58$ \\
\hline R3 (6\% TM) & $75.56 \pm 0.49$ & $10.60 \pm 0.68$ & $7.87 \pm 0.32$ & $1.45 \pm 0.27$ & $181.24 \pm 2.67$ \\
\hline R4 (8\% TM) & $75.33 \pm 0.92$ & $10.43 \pm 0.43$ & $8.08 \pm 0.21$ & $1.45 \pm 0.32$ & $180.44 \pm 6.04$ \\
\hline$p$ Value & $\mathrm{P}>0.05$ & $\mathrm{P}>0.05$ & $\mathrm{P}>0.05$ & $\mathrm{P}>0.05$ & $\mathrm{P}>0.05$ \\
\hline
\end{tabular}

\section{RESULTS AND DISCUSSIONS}

The chemical analysis of the tomato meal used in this study showed that was rich in protein $(20.73 \%)$. It also contains high fibre content $(30.94 \%)$. The high nutrient content of tomato meal makes it a potential feed resource for livestock animals. The crude protein content of tomato meal used in this study was higher than the value of crude protein of tomato waste meal [12] , [13], and also was higher than the value of crude protein of tomato pomacefound by [8], [14]. The variations reported in chemical composition of tomato meal could be due to various factors including varieties of tomato, soil conditions, use of the fertilizations, ripeness and tomato processing conditions.

Effect tomato meal in diet to the chemical composition of eggs of laying hens were shown in Table 2. The results showed that no differences $(\mathrm{P}>0.05)$ in hen egg nutrients and cholesterol between treatments with increasing levels of tomato meal compared to treatment R0 (control = based diet). The achieved whole egg content of crude protein treated by tomato meal up to $8 \%$ was globally similar to the based diet treatment. Also, the fat, carbohydrate and cholesterol of egg obtained on all of the four diets containing tomato meal were similar to the control. The crude protein value of whole egg was higher than that was recommended by USDA [15], that was $6.3 \mathrm{~g}$. According to the World Health Organization the protein in egg has the highest true digestibility of major foods, and its nutritive value is also high because it contains the essential amino acids in the required proportions [1].

Earlier study revealed that laying hens can tolerate up to $6 \%$ tomato waste meal in their diet without any adverse effect on egg production and quality [16]. On the other hand, reference [17] suggested higher inclusion of dried tomato pulp levels up to $150 \mathrm{~g} / \mathrm{kg}$ in broiler chicken diets. The cholesterol value of whole egg was similar to the USDA recommendation $(186 \mathrm{mg})$. Although cholesterol is very 
small part of an egg, it has received as much attention as the major yolk components because of its continuing interest for human nutrition [1]. The result about cholesterol in this study was in line with [18] that reported tomato pomace inclusion in the layers hen had no significant effect on the yolk cholesterol. Moreover, the high content of fibre in tomato meal will definitely limit its use as poultry feed as it interferes with nutrient digestion and absorption [19]. Its inclusion at a lower level may however be an advantage in that it may help to reduce production cost and cholesterol level of egg

Generally, the obtained whole egg nutrients results indicated that the tomato diet up to $8 \%$ have similar quality to based diet, so, that could have beneficial nutritional impact for laying hens. These result suggest that the use of tomato meal in laying hen diets might have positive effects on whole egg quality. So, it is a possible alternative for satisfying consumers' preferences about egg quality.

\section{CONCLUSIONS}

No differences were observed in hen egg nutrients and cholesterol between treatments with increasing levels of tomato meal compared to treatment R0 (control). Thus, tomato meal can be used as an alternative feedstuff in laying hen diets to substitute based diet, at inclusion levels up to $8 \%$ without negative effects on egg quality.

\section{REFERENCES}

[1] B. Vila. Improvement of biologic and nutritional value of eggs. In: J. Brufau (Ed), A. Tacon (Ed). Feed Manufacturing in the Mediterranean Region. Res. Adv. In Res. And Tech. Zaragoza:CIHEAM, 1999, pp 379-396.

[2] V. Ferrante, D. Baroli, S. Marelli, M. G. Mangiagalli, and L. G. Cavalchini. Effect of tomato by-product diet supplementation on egg yolk colour. Ital. J. Anim. Sci. Vol. 2 (Sppl. 1), pp 459-461, 2003.

[3] J. K. Campbell, K. Canene-Adams, B. L. Lindshield, T. W. M. Boileau, S. K. Clinton, and J. W. Erdman, Jr. Tomato phytochemicals and prostate cancer risk. International Research Conference on Food, Nutrition, and Cancer. Held in Washington, DC, July 15-16, 2004.
[4] A. L. Yannakopoulos, A. S. Tserveni-Gousi, and E. V. Christaki. Effectof locally produced tomato meal on the performance and the egg quality of laying hens. Anim. Feed. Sci. Tec. 36, pp53-57, Feb. 1992.

[5] F. Akdemir, C. Orhan, N. Sahin, K. Sahin, and A. Hayirli. Tomato powder in laying hen diets: effects on concentration on yolk, carotenoids and lipid peroxidation. Br. Poult. Sci. 2012, 53 (5), pp 675-680.

[6] L. Rotolo, G. Strazzullo, M. Pagella, A. Brugiapaglia, L. Pozzo, and A. Schiavone. Effect of a tomato extract-supplemented diet on egg yolk pigmentation and lycopene transfer efficiency. Italian J. of Food Sci. 2010, vol. 22, issue 2, p 180.

[7] D. Dotas, S. Zamanidis, and J. Balios. Effect of dried tomato pulp on the performance and egg traits of laying hens. Br. Poult. Sci. 40, pp 695-697, 1999.

[8] M. Jafari, R. Pirmohammadi, andV. Bampidis. The use of dried tomato pulp in diets of laying hens. Int. J. of Poult. Sci. 5 (7), pp 618622, 2006.

[9] Association of Official of Analytical Chemist (AOAC). 1996. Methods of Analysis. 13th Ed. Washington DC., USA.

[10] Tranggono, and B. Setiadji. Kimia Lipid. PAU Ilmu Pangan dan Gizi, UGM, Yogyakarta. 1989.

[11] Steel, R.G.D. and J.A. Torrie. 1980. Principles and Procedures of Statistics. Mcgraw-Hill, New York.

[12] M. W. Squires, E. C. Naber, and V. D. Toelle. The effect of heat, water, acid, and alkali treatment of tomato cannery wastes on growth, metabolism energy value, and nitrogen utilization of broiler chicks. Poult. Sci. 71, pp 522-529, 1992.

[13] A. Alvarado, E. Pacheo-Delahaye, and P. Hevia. Value of a tomato by-product as a source of dietary fiber in rat. Plant Foods Hum. Nutr. 56, pp 335-348. 2001.

[14] USDA Food Safety Inspection Service. Shell Egg from Farm to Table. 2010. http://www.fsis.usda. gov/ pdf/ shell_eggs_from_farm_to_table.pdf.

[15] A. King, ang G. Zeidler. Tomato pomace may be a good source of vitamin E in broiler diets. Calif. Agric. 58, pp 59-62, 2004.

[16] M. Habanabashaka, M. Sengabo, and I. O. Oladunjoye. Effect of tomato waste meal on lay performance, egg quality, lipid profile and carotene content of eggs in laying hens. Iranian J. of Appl. Anim. Sci. 4 (3), pp 555-559, 2014.

[17] N. A. Al-Betawi. Preliminary study on tomato pomace as unusual feedstuff in broiler diets. Pak. J. Nutr. 4, pp 57-63, 2005.

[18] A. Safamehr, H. Malek, and A. Nobakhat. The effect of different levels of tomato pomace with without multi-enzyme on performance and egg traits of laying. Iranian J. Appl. Anim. Sci. 1, pp 39-47, 2011.

[19] S. Leeson, and J. D. Summers. Scott's Nutrition of the Chicken. 4th Edition, pp 466-468. 2001. Academic Press, Guelph, Ontario, Canada. 